\title{
Community Based Ecotourism Development at Kahitestsa Forest and Environs Awi Zone, Ethiopia: Opportunities and Challenges
}

\author{
Ayana Fiseha \\ Lecturer at Bahir Dar University College of Business and Economics, Department of Tourism and Hotel \\ Management, Bahir Dar, Ethiopia
}

The research focuses on investigation of opportunities and challenges of community based ecotourism (CBET) development in kehitastse forest and environs. Qualitative research design was employed and 40 key informants were selected purposively from 6 different target groups. Observation was also used to deeply investigate important information with details of structured observation check list. Information was also collected and recorded through Photographs. Secondary data source such as, journal articles, reports, proclamations and policy documents relevant to the topic under study were also reviewed and used for analysis. The process of data analysis and drawing of conclusion was employed qualitative analysis method. It was contextualized and themed in to similar characteristics and triangulated to reach in to conclusion. The finding shows that the area is rich in natural and cultural tourism resources for CBET. Moreover, accessibility and proper demarcation of the forest, engagement of micro finance (credit and saving) institution towards CBET, engagement of cooperative institutions to involve in CBET activities, availability of tourism policy and ecotourism guidelines in the area are some of opportunities for community based ecotourism development. However, conflict between human and nature, lack of capacity, engagement and cooperation among stakeholders to involve in CBET business, lack of infrastructures and promotion of the forest are some of challenges for CBET development. It is recommended that environmentally sound, culturally friendly and economically feasible community-based ecotourism should be developed in the destination to bring local sustainable development.

Keywords: Opportunities, Challenges, Community Based Ecotourism Establishment, Sustainable Development, DOI: $10.7176 / \mathrm{JTHS} / 43-04$

Publication date:September $30^{\text {th }} 2019$

\section{Introduction}

Tourism is fastest growing and largest industry in the world (Kassegn B. and Endalkachew T., 2018). International tourist arrivals reached 1.14 billion in 2014 which is 51 million more than 2013 and accounts for more than $10 \%$ of total employment and generating more than US $\$ 1.5$ trillion in international tourist receipts and US $\$ 7.6$ trillion (9.8\%) of the world's GDP. the total earning from tourist trips are predicted to increase to $\$ 1.6$ billion by 2020 (UNWTO, 2014) and total tourist trips predicted to be increased by 1.6 billion 2020 (Kassegn B. and Endalkachew T., 2018). The international tourism will continue to grow at an annual rate of $3.3 \%$ through 2030 (UNWTO, 2014).

In recent years, ecotourism and protected areas have strong connection: the relationship between natural resources and ecotourism as well as people and economics has received high attention from academics, government and non-government conservation and development agencies in many nations (Creswell and $\mathrm{Ma}$ Laren, 2000). This is due to its potential benefits considered mainly from environmental and economic perspectives (Weaver and Lawton, 2007). It provides economic benefits to local people while simultaneously conserving natural resource through low- impact, non-consumptive use (Kelley, 2009). Hence, it is best tool and part of the strategic response to integrate conservation and development projects for challenges of environmental, socio-cultural and economic sustainability especially in developing countries (Duffy, 2006). This results the development of ecotourism and to be widely viewed as a positive means of improving people's standard of living (UNWTO, 1997). As result, most nations have made efforts to protect natural resources (Woodley, 1999).

Ethiopia provides an authentic African experience with a wealth of archaeological, cultural, religious and natural wonders to explore (B. M. K. Robinson AndJ. A. Jonker (2016). Ethiopia has a tremendous but to date only a partially untapped tourism potential including unique natural topographic beauty and biodiversity that is profoundly the pillar for ecotourism development and wildlife conservation (Kassegn B. and Endalkachew T., 2018). Ethiopia has 21 national parks, 20 controlled hunting areas, 4 biosphere reserves, 80 national priority forest areas, 2 wildlife sanctuaries and many other commercial ranches, botanical gardens, community conservation areas, and also wildlife reserves Young (2012) cited in (Kassegn B. and Endalkachew T., 2018). 
Table 1.1: Fauna and Flora Species Found in Ethiopia

Species Category Total No. of Species

No. of Endemic Species

$\begin{array}{lll}\text { Mammal } & 320 & 39 \\ \text { Birds } & 918 & 19 \\ \text { Reptiles } & 240 & 16 \\ \text { Amphibians } & 71 & 30 \\ \text { Fish } & 172 & 38 \\ \text { Insects } & \text { Arthropod } 1225 & 7 \text { (Butterflies) } \\ \text { Vascular Plants } & 6500 & 625\end{array}$

Source: EWCA, (2013) and Ahmed M. (2017).

A few hundred years ago more than $63 \%$ of Ethiopian land was covered by dense forests; but this figure was decreased to 3\% (Gebremarkos, 1998). However, currently, it increased to $14 \%$ of total area due to green economic policy to protect climate change (SDPASE, 2008). This is an opportunity to develop different types of tourism activities (Henze, 2007). Ethiopia has potential to earn more than 20 billion birr annually from ecotourism. Regardless of this opportunity, Ethiopia earns only 60 million birr annually. It stands among the lowest tourism beneficiaries in Africa (EWCA, 2015). Ethiopia has protected areas which are rich in valuable natural resource such as medicinal plants, endemic plants and animals, amazing variety landscapes, and beautiful birds, massive mountain chains, enormous waterfalls, dense and green jungle forests (Viva Ethiopia Tour, 2014) and world heritages, archaeological and historical resources, diversified culture, colorful ethnic groups, historical churches and monasteries, local art and artifact cultural tourist attractions (Ethiopian Tourism Commission 1995) are some of potential ecotourism resources to develop CBET.

It is also true that the Kehitesta forest has enormous ecotourism potential resources discovered by the same researcher (Ayana F., 2019) entitled as "An investigation of Tourism Potential, Communities' Awareness and Engagement towards Community Based Ecotourism Development in Kehitastse Forest and Environs, Ethiopia”, but, current study is not included under previous journal article. The objective of this study is:

$>$ To investigate the opportunities and challenges for establishment of CBET at Kahitestsa natural forest,

$>$ To assess the opportunities and challenges for establishment of CBET at Kahitestsa natural forest,

$>$ To identify and propose ways of resources and local communities Sustainable

\section{Review of related Literature}

Tourism has a negative as well as positive impact on both people and nature. Inappropriate tourism development and practice can degrade habitats and landscapes, deplete natural resources, and generate waste and pollution (Denman, 2001). The increase in number of tourists in $21^{\text {st }}$ century resulted in mass tourism which has adverse effect on sustainability of resources. To solve such problem the concept of Ecotourism is emerged (Kelly, 2009). Ecotourism is thus, nature-based tourism which minimizes the negative environmental, economic and social impacts often associated with mass tourism; maximizes environmental conservation; and improves the livelihoods of local people (Cater and Lowman, 1994). Its aim is to develop responsible travel to natural areas that conserves the environment and to sustain the wellbeing of Community (UNWTO, 1997); consequently, it is becoming popular and responsible tourism in many developing countries at recent years (Kelly, 2009). Responsible tourism can help to generate awareness, to support conservation and local culture, and to create economic opportunities for countries and local communities. WWF is taking action to reduce negative impacts, and to encourage responsible tourism that enhances not only the quality of life, but also natural and cultural resources in destinations (Denman, 2001).

Ecotourism, thus, preserves natural resources while profiting from them (Hardyment, 2003). It enhances participatory natural resources conservation, creates jobs and improves livelihood of the local community and marketing of local products where by contributing to sustainable development (Amogne A., 2014, P1); it helps to manage natural resource by generating income for the local communities and diversifying their livelihoods, enhances community development and bringing people closer to conservation (Kiss, 2004), provides incentives for the conservation of the forest resources (Edleman, 2006).

CBET is alternative form of ecotourism where the local community has substantial ownership, management, control and involvement in every aspect of tourism in their area, and a major proportion of the benefits remain within the community (Denman, 2001 and Sproule, 1996). Thus it has emerged to integrate natural and cultural resource conservation in to local income diversification in the developing world (Miller, 2004). The main aim of Community based ecotourism is thus, to conserve the ecological environment and maintain sustainable use of resources while providing ecological experience to travelers, enhancing economic benefits to local community based on ecological principle and sustainable development theory (Hongshu and Mintong, 2009).

Blamey (2001), Bramwell and Sharmen (2000) developed basic principles of sustainable tourism development

such as holistic planning and strategy making; preservation of essential ecological processes; protection of 
both human heritage and biodiversity; and development to ensure that productivity can be sustained over the long term for future. Lowmen (2004:2) has also justified in another way that "ecotourism follows two important principles of sustainability namely, promoting biodiversity conservation and supporting the local economies."

physical features, economic development, population characteristics, lifestyle, life cycle and personality, local governance structure, suitable policy and legislation, awareness, skill and attitudes of local communities towards ecotourism development, inter-community relationships, stakeholder collaborations, partnerships with NGOs and tour operators important attraction potentials, technology, the price, frequency and speed of transport, as well as the characteristics of accommodation, facilities and travel organizers and other related factors affect development as well as success of community-based ecotourism at particular destination (Fennel, 1999).

Natural environment is part of the tourism resources on the destination (Foday Y., 2015). The land surface of the earth is composed of a variety of landforms; such an evenly distribution of Physical features have fundamental significance for tourism development. The world's forest resources also deserve special function for tourism development. In most developed countries forests and woodlands are valued for recreation and wildlife protection, in contrast to the exploitation which occurred in the past. Multiple uses are characteristic of such areas, and careful management is essential to protect the resource. CBET is one mechanism of protecting the resources as well as simultaneously benefiting local community (Stephen William, 2009). The wildlife tourism is becoming an increasingly important component of tourism industry in the world. In recent years, increased demand for closer interaction with wildlife in their natural habitats is encouraging sustainable growth of wildlife tourism (Green and Higginbottom, 2001). Climate is also considered as encouraging as well as limiting resource for development of tourist flow to destination. Hence, accurate information on the climate of the destination is very necessary; many types of recreation, from sunbathing to skiing, are weather- dependent; climate largely determines the length of the tourist stay, destination's development and operating costs; sales of beverages and leisure equipment are affected by weather changes, In most destinations, the problem of seasonality seriously affects profitability and employment in the tourism industry (Brai G., Boniface and Chris C., 2005).

Although few suitable areas are pristine wilderness for tourism development, there are also challenges (Stephen William, 2009). It demands and passes variety of elements and difficulties than the conventional tourism (Fennel, 1999) such as rigged feature of the land; local communities demand for forestry, and pasture for grazing, hydroelectric power generation and mineral extraction so, tourism has to compete with these activities. To solve such problems, over-development such as involving the construction of roads and cableways is a matter of growing concern. This has led many authorities to discourage the more popular forms of tourism in favor of activities in harmony with the natural environment which will sustain the resource for future generations (Stephen William, 2009). Wildlife continues to be lost rapidly across the planet in spite of the effort of conservationist organizations towards natural resources protection (Kassegn B. and Endalkachew T., 2018). Government agencies are key actors to plan for development of ecotourism (Weaver et al., 1996). Products of services provided, price structure, organization among businesses, marketing, financial issues, resistance by local residents, government support, and the existing natural resource base can be a challenges and affect the likelihood success of businesses in the ecotourism establishments (Fennel, 1999). Lack of government programs are major barriers to entrepreneurs entering the ecotourism sector. Thus, government should encourage ecotourism sector through incentives (e.g. grants and low-interest loans), marketing and promotion, or business counseling and training to minimize barriers. Government agencies also create barriers through regulations, taxes, and bureaucratic red tape, or because of a lack of interagency cooperation and coordination (Weaver et al., 1996. On the other hand, businesses in the ecotourism sector often struggle to survive because of scarce resources and their owners lack of business experience particularly tourism related experience. Obtaining financial resources to operate the CBET business for the first few years is among the most important barrier to doing business (McKercher and Robbins, 1998). Financial problems occur because of difficulties in obtaining loans from financial institutions (Weaver et al., 1996); as a result, it is higher than expected costs and slower than anticipated business growth (McKercher and Robbins, 1998).

\section{Description of the Study Area and Research Methodology 3.1 Description of the Study Area}

The study was conducted in 2017 to 2019 at kehitaste forest which is one of largest Natural dense state protected forests found at Awi zone, Amhara National Regional State of Ethiopia. The forest is located between 10 Kebeles within 3 woredas namely; Ayikalta-ankuri, Gazahara-Awidi and Ageyasta-Agta kebeles at Fagita Lekoma woreda side; Dankury Muli (askuna Abo, Lemlem (Zufari), Golo (Bari), Asa Ber (senbaka) Kehitestse (Zik) kebeles at Banja Shekudad woreda side; and Bakona and Mesela kebeles at BanjaShekudad. The total area of the fores covers 5266.35 hectors. 


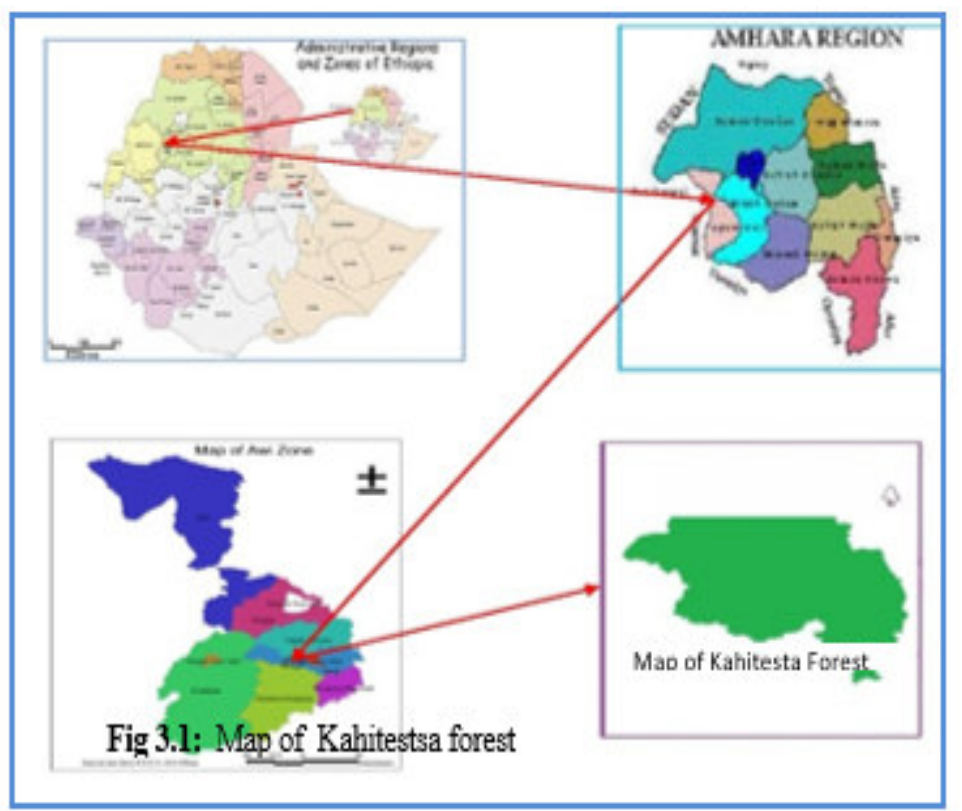

Fig 3.1: Map of Kahitestsa forest

The geographical position of Kahitestse forest is $10^{\circ} 57^{\prime} \mathrm{N}$ and $36^{\circ} 56^{\prime} \mathrm{E}$ The topography of Kahitestsa forest is characterized by plain, plateau, hills and valley land features (Ayana 2019). The topography ranges from 1900- 2800 meters above sea level. The diverse topographic features of the area have resulted diverse climatic conditions. Agro ecologically, the forest is classified as Dega (35\%), and Woyna Dega (65\%). The area is humid and there is heavy intensity of rain. The average annual rain fall is $2000 \mathrm{~mm}$ and Cloud condition covers $92 \%$ of the sky (Awi zone natural resource and forest bureau, 2018). There is high rain fall during July to August; Crop production is the main socio economic activity of local communities during rainy season although there is increasing utilization of water for irrigation during dry season to maximize the total production. Cattle, sheep, goat, horse, ass, mule and poultry husbandry are also sources of income to communities. Demographics, based on the 2009, census conducted by central statistical agency (CSA), the total numbers of population who live in these kebeles are 34917 (BOFED, 2012).

\subsection{Research Methodology and Materials}

\subsubsection{Sources and Methods of Data Collection}

In depth expert interview, observation and secondary data source were used to get information from multi-direction of sources. Face-to-face personal interview was used since it is easier to guide and grasp the interview agenda and it is single person's ideas. It is also safe to record the interview for evidence since there is only one voice to recognize from one person talking at a time. It comprises 40 key interview informants from 6 different target groups. The rationale for selection of these target groups is knowledge, experience and responsibility of samples to get deep information regarding to their interest opinions and feelings to contribute CBET development (see Table 3.1). Factual information was also included in interview questions. List of questions as interview guide were prepared. So, deep information was collected through taking detail notes. 
Table 3.1: samples of the study

\begin{tabular}{|c|c|c|c|c|}
\hline S.N & $\begin{array}{l}\text { Sample } \\
\text { stakeholder }\end{array}$ & Area of selection & Quantity & Rationale for selection \\
\hline 1. & $\begin{array}{l}\text { forest security } \\
\text { work forces }\end{array}$ & From the Kehitastse forest & 6 & $\begin{array}{l}\text { Day to day responsibility and } \\
\text { experience for safe guarding of the } \\
\text { forest }\end{array}$ \\
\hline 2 & $\begin{array}{l}\text { Tourism } \\
\text { experts }\end{array}$ & $\begin{array}{l}\text { representatives from Awi zone, } \\
\text { Fagita Lacoma, Banja Shekudad } \\
\text { and Ankesha Gongo wordse } \\
\text { culture and tourism bureau (1 } \\
\text { from each) }\end{array}$ & 8 & $\begin{array}{l}\text { Expertise and responsibility } \\
\text { concerning tourism in general and } \\
\text { CBET in particular }\end{array}$ \\
\hline 3 & $\begin{array}{l}\text { Natural } \\
\text { Resources } \\
\text { and Forest } \\
\text { Experts }\end{array}$ & $\begin{array}{l}4 \text { natural resources and forest } \\
\text { office representatives of which } \\
1 \text { for each words }\end{array}$ & 8 & $\begin{array}{l}\text { Expertise responsibility concerning } \\
\text { the forest safety }\end{array}$ \\
\hline 4 & $\begin{array}{l}\text { Micro finance } \\
\text { and cooperative } \\
\text { expert }\end{array}$ & $\begin{array}{l}3 \text { Micro finance and saving } \\
\text { representatives of which } 1 \text { for } \\
\text { each words }\end{array}$ & 6 & $\begin{array}{l}\text { Expertise and responsibility } \\
\text { concerning loan and saving }\end{array}$ \\
\hline 5 & $\begin{array}{l}\text { cooperative } \\
\text { office }\end{array}$ & 1 representative from each word & 6 & $\begin{array}{l}\text { Expertise and responsibility } \\
\text { concerning the cooperative }\end{array}$ \\
\hline 6 & $\begin{array}{l}\text { Community } \\
\text { leaders }\end{array}$ & $\begin{array}{l}\text { From } 3 \text { neighboring kebeles of } \\
\text { the forest }\end{array}$ & 6 & $\begin{array}{lll}\begin{array}{l}\text { Leadership } \\
\text { experience }\end{array} & \text { responsibility and } \\
\end{array}$ \\
\hline & Total & & 40 & \\
\hline
\end{tabular}

Observation is the other main instrument used to collect and record important information about potential tourism resources, services, facilities, infrastructure as well as challenges for development of CBET of study area. Details of Structured observation check list was used.

Secondary data source such as, journal articles, reports, proclamations and policy documents relevant to the topic under study were also reviewed and used for analysis.

\subsubsection{Method of Data Analysis}

The process data analysis and drawing of conclusion was employed qualitative analysis method. It was contextualized and themed in to similar characteristics and triangulated to reach in to conclusion. Textual description was used to present the results of the study.

\section{RESULTS AND DISCUSSION}

\subsection{Opportunities for Community Based Ecotourism Development}

\subsubsection{Ecotourism Resources in and around the Forest}

In most of developed countries forests and woodlands are valued for recreation and Wildlife protection, (Stephen William, 2009). In this concern, the researcher (Ayana F., 2019), in previous journal article discovered that the Kehitastse Forest is rich in valuable natural resources such as jungle forests itself, fauna and flora species, landscape and water bodies, favorable climate which is suitable for inhabitants of flora and fauna biodiversity as well as cultural resources near and around the forest are some of potential resources that create opportunity to develop community based ecotourism. The forest is protected although some problems are observed. It has favorable climate for biodiversity habitat. This creates great opportunity to develop CBET specifically "niche tourism" like wildlife tourism, bird watching tourism, photographing tourism and controlled hunting tourism which benefits local communities. This can further lead sustainable development of protected areas and the community themselves as role players. Hayward, (2000) assures this as, Ecotourism enhances preservation of natural resources while profiting from them. On the other hand, Stephn William (2009) discuses as Physical features of land and sea are unevenly distributed throughout the world which has important implications for climate variation, population distribution, economic development, and communication. Mountain ranges are found in every continent and attract many tourists interested in sightseeing. This is due to the variety of scenic features. 


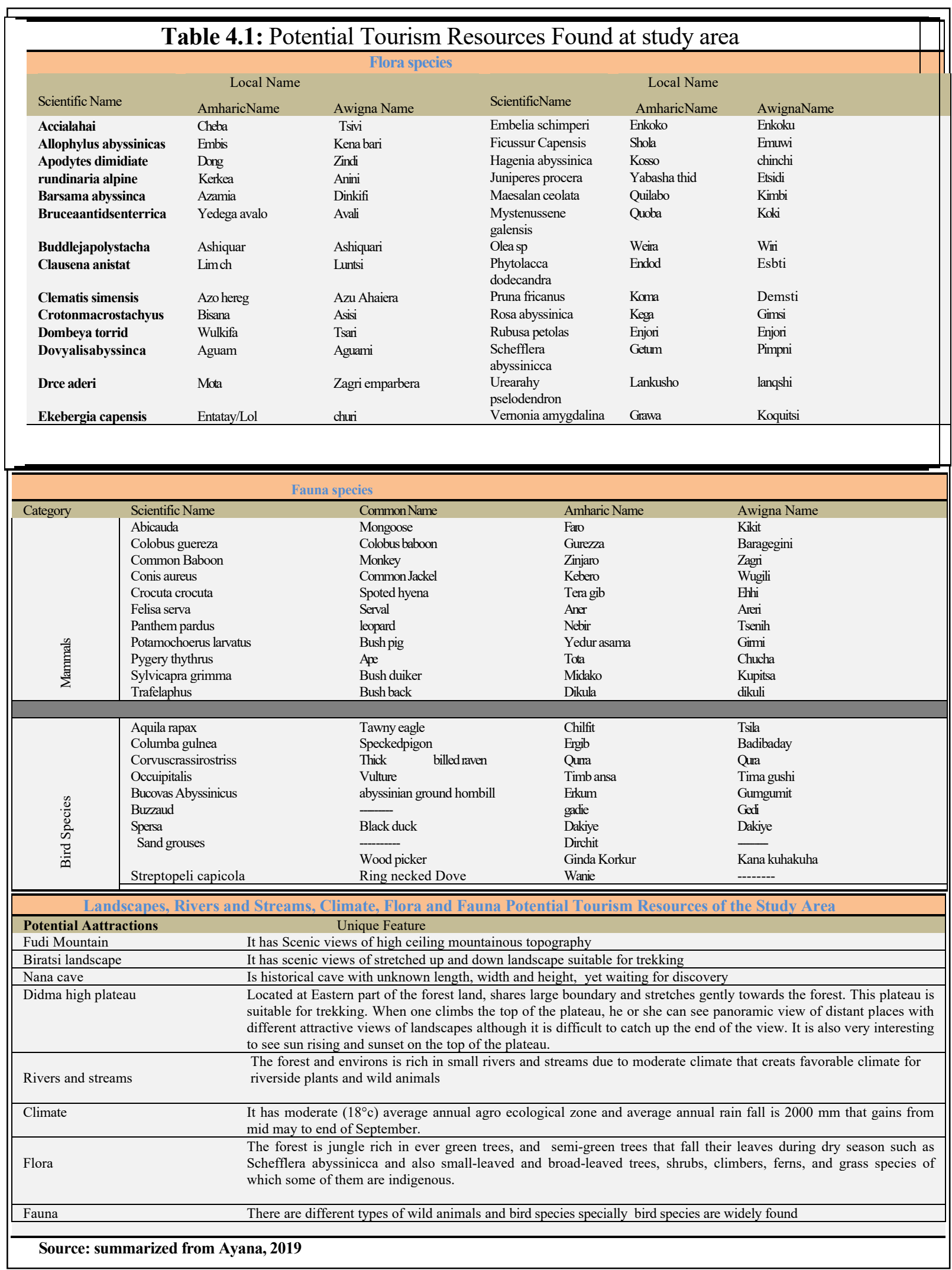

\subsection{Proper Demarcation of the Forest}

Improper demarcation of protected areas can be the major challenge for development of CBET at protected areas. Properly demarcating and trying to expand the boundary of protected areas may dislocate local communities from their own land area. This may cause problem of land ownership right and need negotiation with land owners and compensation payment which is very difficult and expensive to implement. Coad et.al (2008) 
illustrated the consequence of displacement of local communities from conservation areas: removal of people from their homes by force and economic dislocation, the exclusion of people from particular areas in the way that harm their livelihood. These make them to be powerless to collect firewood or wild foods, to hunt, or fish, or unable to walk to their farms on the other side of the park, they can't live as they were before. Pearce (2005) also pointed out the negative impact of displacement on socioeconomic activities: landlessness; unemployment; homelessness; marginalization; loss of right to use common property and other social disarticulation. For example, 500 people were removed from the Nechisar National Park in southern Ethiopia in 2004 and resettled outside its borders (Ahmed M. 2017).

The other research finding conducted at Borena-saynt national park shows that, there are shortages of cultivable land and low fertility of the soil which have forced the households for overgrazing by livestock; expansion of agricultural activity towards the forest; expansion of settlement towards the forest area; demand of wood for household fuel and construction have created problem to the park. Due to these problems and population pressure, further encroachment of the park is inevitable. even though 36 hectares of farmland and 26 hectares of grazing land that were occupied illegally, have incorporated in to the park after giving the appropriate compensation to the farmers, still large part of the park which was changed in to farm land and grazing land was decided to be out of the demarcation considering the long run impacts of its incorporation into the park (Amogne A. 2014).

According to community leader and Forest expert (2019), however, the issue of demarcation is immaterial challenge at Kahitaste forest. They expressed that "The forest is properly demarcated in 1997. Regardless of shortage and decrease of land fertility, currently, communities cannot use the forest for crop production farming due to proper demarcation. This is strictly forbidden by law and result in punishment." Observation of the researcher confirms this experience to be duplicated at other protected areas of the world especially in developing countries where demarcation problem is chronic issue.

Therefore, existence of proper demarcation is one of opportunities to develop CBET which can enhance sustainable development of the protected area and communities' livelihood. This in turn can lead land ownership right of local communities in better way and vis-a-vis. As Sofield (2003) and Cole (2006) advocates this issue as CBET can facilitate and enable the host communities to control tourism development. They can gain power to retain the rights to own, protect and develop their land. This ownership and control of natural resources can bring sustainable development. (Foday Y. 2015).

\subsection{Engagement of Micro Finance (Credit and Saving) Institution towards CBET}

The economic level of local communities and owners affect the success of business in ecotourism sector. Obtaining beginning capital to operate the CBET business is among major challenges to do business for the first few years (McKercher and Robbins, 1998, and Weaver et al., 1996). Financial problems occur because of difficulties in obtaining loans from financial institutions. Tourism entrepreneurs need incentives from the government for starting up and to expand their business activities. This can be through provision of low interest loans (Weaver et al., 1996).

According to Experts (2019) from Bureau of Culture and Tourism, lack of developed funding mechanisms for tourism businesses is one of major reasons to fail to develop CBET. They lack financial capacity to cover expected costs for business development and growth such as to run the operation, training, conservation, and marketing tasks. They added that they are not using existing opportunities of tourism since there are many challenges. Lack of budget takes the lions share. Similarly, Experts (2019), from Natural Resource and Forest Bureau replayed that communities are engaged to be involve and benefit from natural and agro forestry associations. However, budget problem is one of major challenges to run the operation; to provide the training and to pay salary to employee.

Microfinance credit and saving institutions are among governmental financial institutions to ease these problems. According to Expert (2019) from Micro finance and saving institution of Amhara region,

"institution provides the loan to any loan seekers if they fulfill pre-stated criteria such as: (1) they should believe as the business is feasible and propose business plan; (2) they should have work interest; (3) if they are poor and need the loan without guaranty, they should come in group (association); 4) the loan seeker should have good ethics; (5) the age of individual loan seekers should be above 18 years; (6) they should provide evidence that shows free from any loan; (7) for individual creditor who do not need loan in group properties like equileptes tree can be used as guarantee. The regulation supports more than $70 \%$ females to be beneficiary. The major challenges to work with local communities, however, are awareness problems of local communities how to invest, save, and return back what they have borrowed." To alleviate this problem, "'the loan provision is supported through awareness creation training. The institution provides awareness creation training, way of saving, warranty, rights and responsibilities of individual loan seekers, benefits of credit and saving, and the return skill of the loan. Borrowers should return at least $18 \%$ of the loan per year. The 
training is provided cooperatively with other stakeholders to satisfy diverse business needs of loan seekers. The other lack of sufficient experts in the office and budget are other problems although all of those challenges are decreasing from time to time since awareness and benefit from the loan is highly increased." He added.

According to Muluken (2017) who is expert of Fagita lakoma woreda credit and saving institution, more than $99 \%$ of loan is returned within given period of time in 2016 fiscal year which is significant change compared to previous years. He also added that there is progress of budget from time to time although it is not still adequate since there is high increase in loan seekers.

Experts (2019) of credit and saving institutions stated that they have experience of loan provision to loan seekers for agro forestry business both in groups and individual loan holders, but they replayed as there is no still experience of providing loan to CBET activities Since nobody proposed for such businesses. Their institution is open if CBET entrepreneurs propose the feasibility study and fulfill the stated criteria. Therefore, there is an opportunity to get the loan from Microfinance credit and saving institutions if CBET is established at study area and intended for loan.

\subsection{Engagement of Cooperative Institutions to Involve in CBET Activities}

CBET is a group business that needs cooperative relation of community members in formalized way. To realize this, it needs support from Cooperative Institutions. They can provide awareness creation and extension training, expertise support and follow up, experience sharing with other area. Accordingly, experts (2019) from Fagita lakoma, Banja Shekudad and Ankasha woredas expressed their engagement to provide their usual support. They replayed that, "Cooperative institutions have experience in supporting different associations with different projects for long years including natural and agro forestry associations of local communities that have brought progressive change and benefit from association activities."

According to Amhara regional state of cooperative associations, proclamation 220/2007 E.C, The criteria to establish cooperative associations includes: (1) engagement to be member of association, (2) legal, ethical and normal in health condition, (3) able to pay registration fee, (4) resident at work area and able to participate in the activities, (5) responsible to accept and accomplish regulation of the association, (6) not member of other similar association and (7) not employee of the association. This proclamation is not complex and difficult for interested individuals to join the association, rather it motivates to involve and benefit from the association. This is one of an opportunity to develop CBET business at study area.

\subsection{Availability of Tourism policy and Ecotourism guidelines}

Ministry of Culture and Tourism of Federal Democratic Republic of Ethiopia has developed tourism developmental policy and community based ecotourism guide lines that direct the level stakeholder's involvement and mandates in resource utilization and management.

Ethiopia Tourism Development Policy (2009) states that, the tourism policy is an expression of the government's commitment that guides the overall development of tourism in Ethiopia; it serves as an umbrella to guide the public and the private tourism sector players. At the same time, the public and the private sectors have distinctive roles in the tourism development of the country. The policy also briefly expresses that government seeks to see Ethiopia's tourism development to be led responsibly and sustainably and contributing its share to the development of the country by aligning itself with poverty elimination.

As it can be seen from above convey, the emphasis of the policy document is to directly benefit local communities from tourism development through developing the existing and new tourist attractions in variety scale and quality. It also calls for active participation poor communities and greater cooperation between the public and the private sectors. Sustainable tourism development as well as conservation of resources and the participation of local communities in tourism are seen by the Government of Ethiopia as central elements of tourism development. One of the mechanisms to achieve this policy is through CBET development. Hence, the Ministry has prepared community based ecotourism guideline that elaborates the mandates of concerned stake holders namely, the Ministry of Culture and Tourism, the Bureau of Culture and Tourism, Ecotourism-service providers and attraction site owners, respective local communities, across Ecotourism attractions, nongovernmental organizations working, on Ecotourism development, Higher education institutions, media and duties and responsibilities of tourists. The rationale of the Ecotourism guideline is to enhance development ecotourism and optimize the anticipated stake holders' benefits especially local communities through maintenance of attractions and ecotourism services as well as preventing possible adverse impacts on Ecotourism attractions. Therefore, this is a great opportunity to develop CBET at Kahitastse Forest.

\subsection{Challenges of Community Based Ecotourism Development}

Regardless of positive implications considered as opportunities for CBET development, there are also some challenges that affect the development of CBET at study area. These include unsustainable use of the forest and 
human-wild life conflict; financial-constraints; lack of capacity, engagement and cooperation among stake holders to involve in CBET business; lack of infrastructure, and marketing and promotion problems. Hence it is important to deal to take necessary measures.

\subsubsection{Conflict between human and nature}

Development of CBET passes many challenges mainly due to conflict between human and nature. Hence, assessment of conservation strategy is necessary to identify the level of conservation and local communities influence on natural resource and then to find the solutions that lead to sustainable development of the forest since it is based on ecological, socio-cultural and economic sustainable development principles and strategy.

Natural resources and forest bureau (2018) report justifies that $98.6 \%$ of local communities are agrarians with traditional activity who are highly dependent on natural resources as source of income with increased family size (averagely 5 per household) but, without any increase of diversified source of income. On the other hand, there is decrease in productivity of land and high need of fertilizers as well as dissected land use. These all together forced local communities to use the forest for uncontrolled grazing, house construction, fencing, household utensils, lumbering, and fire wood and charcoal production. Similarly, Community leaders and forest security guards (2019) implied the sustainability problem of the forest due to local communities' pressure. They said that, local communities do not consider the advantage of forest sustainable development; rather they target towards short term benefit like uncontrolled grazing and illegal use of trees for housing, household materials, lumbering, fire wood and charcoal.

After critical observation, the researcher has also founded the same problems. Currently, the forest is not managed and developed. The economic activities practiced in the forest by local communities have negatively affected the potential tourism resources. Rearing of domestic animals such as cattle and sheep, goats, donkeys as well as horses in the forest is not prohibited; rather, everybody can access and raise their livestock except farming for crop production. This is the dominant cause for depletion of forest sustainability. The use of forest for feeding damage grasses, shrubs, and other flora specious. Their daily walk in the forest can aggravate soil degradation and erosion. According to EWCA, (2009), this pressure on natural resources, however, is strictly prohibited by Ethiopians wildlife development, conservation and utilization regulations No. 163/2008. It highlight as human activities like hunting, cultivating, grazing, settling in, burning vegetation, deforestation or exploiting other natural resources inside the national parks and wildlife sanctuaries is strictly prohibited. However, inside the rest of the protected areas, access to natural resources use may be allowed under regulatory procedures on sustainable basis.

The practice of modernized animal husbandry, strict forest control mechanism as well as diversification of communities' income sources like development of CBET can minimize the situation. As B. M. K. Robinson And J. A. Jonker, (2016) suggests diversification of the economy and export driven growth are important contributors to sustainable economic growth. Tourism's contribution to poverty alleviation and job creation can be powerful. Duffy (2006) rationalizes CBET as it is part of strategic response to challenges of Environmental, socio-cultural and economic sustainability; for this reason, many of developing countries have developed CBET to alleviate the poverty stage of country. Amogne A., (2014) points out one major advantage of ecotourism as, it creates non-farm livelihood opportunities for the local communities who are relied on the agriculture as source of income.

The other series problem observed at forest is illegal cutting of trees for housing, household materials, lumbering, and fire wood and charcoal production purposes. In this concern, the use of fire wood has high burden than others. This is due to lack of other source of energy for local rural people. This enforces them to utilize the forest mainly those communities who do not have sufficient land to fire wood plantation. Some people also collect the fire wood for commercial purpose at local towns due to economic dependency on natural resources. These circumstances can be reduced through use of other sources of renewable energy like biogas, solar energy, wind or hydroelectric energy as option. The communities also use the forest for construction of their homes and produce household utilities and farming tools. Presently however, Charcoal production, is minor problem due to expansion of 'decarance tree' agro forestry which is mainly planted for charcoal production. This practice is cultured throughout the surrounding areas. The forest is also extensively used for bee keeping and medical plants. Although, the use of medical plants minor impact since it involves cutting of leaves and root, bee keeping has not any adverse effect to the forest; rather it enhances reproduction of flora diversity. This should be farther developed in modern way since the climate is favorable for this activity. Hence, it can be developed as 'niche tourism'.

Human-wildlife conflict is another major challenge for sustainable development of wild life at protected areas. It is becoming a serious threat to the survival of many endangered species and posing socioeconomic problems on local communities in the world and a global problem experienced especially in areas where wildlife and human population co-exist and share limited resources and boundaries (Eniang et al. (2010). A set of global trends has contributed to the acceleration of human wild life conflict world-wide. These may be due to human population growth, land use transformation, degradation and fragmentation (Hill, 2000; Demeke and Afework, 2013). Local Communities use different traditional methods to reduce wildlife impacts: guarding the crop and livestock, chasing by dogs, placing scarecrow, trapping, using physical barriers like digging trench round the 
farm as wildlife impact control measures. Persons who guarded the crop permanently faced problems like: absence from meeting and other social relations, absence or withdraw from school and absence from market and other journeys, broke their social relation such as participating (habtamu, 2016).

Natural resource and forest expert interviewees (2019) responded as wild animals create negative impact on local communities: they damage crops, and human, wild animals affect drinking spring water to be unsafe to human consumption and they also create anxiety on local communities. They added that, Local Communalities react in different ways to protect from these problems. They hunt; kill and chase dangerous animals such as fox, monkey, ape, serval, leopard hyena, mongoose and bush pig although killing of wild animals is forbidden by low. Currently, however, human impact is decreasing from time to time due to fear of punishment unlike past years.

Likewise, Key informant interview respondents of community leaders and securities from selected sample sites stated the problem of human-wild life conflict. They denoted that,

"Hyena eats domestic animals; monkey damage goats, sheep and mainly crops; ape and bush pig harm crops; fox leopard and serval attack domestic animals and people. To protect these problems local communities hunt, kill, and chase wild animals from the habitat; but the intensity of illegal activity is decreasing due to local communities increase in awareness from time to time about rule and its consequence."

Research reports show that, similar problem is observed at many protected areas of Ethiopia. For instance, as Swayne's Hartebeest Sanctuary in Ethiopia is faced with challenge. Local people who live around the Sanctuary depend on the natural resources of the sanctuary for their livelihoods in different ways. There is high illegal encroachment to the sanctuary particularly high number of livestock with their nomadic. This situation causes high fight on forage between wildlife and livestock (over grazing), wildlife behavioral change and disturbance during sensitive period (breeding time) and influence unsatisfied visit to tourists since the number of livestock is greater than wildlife in the area. There are also collecting acacia trees for fire wood and thatching grass illegally from the park (Teyiba A. et.al., (2017)

The other example of human impact in protected areas of Ethiopia is at Alatish National Park where local communities affect the park through repeated fire, hunting and conflict of interest over resource utilization between foreign tribal nomads and local communities, unwise utilization of fishing, water stress specially during dry season, human-wildlife conflict, collecting of plants for to produce sticks, rope, furniture and house construction, but there is also an unsustainable gathering of non-timber products like wild honey, fruits, medicinal plants, mushrooms and roots as well as gum and incense (Kassegn B. and Endalkachew T. 2018).

Generally, the result of study implies that conservation strategy of the Kahitaste forest is not strong. There is human wild life conflict at study area. Wild life highly influence the life of local community: They damage domestic animals, crops and human. They create anxiety to human and cause drinking spring water to be unsafe to human consumption. People take different measures to protect from these problems. They trap, kill and/ or chase. These are chronic problems for development of CBET at conservation area. Anyhow, CBET should be developed through maximizing those opportunities and minimizing challenge through strategic planning and mobilizing concerned stakeholders. Development of community based eco tourism and benefiting communities from community based eco tourism can create the sense of ownership of communities that enhances sustainable development of natural resources. Hence, the more livelihoods of local communities improved, the more protected area will be development in sustainable way and vice versa.

\subsubsection{Lack of Capacity, Engagement and Cooperation among Stakeholders to Involve in CBET Business} One of the main policy issues and strategies of Ethiopian tourism policy is strengthening the collaborative relationship among actors in tourism development (Ethiopian tourism development policy, 2009). Regardless of this briefly stated policy, Lack of integration and participation of the main actors are most common problem on CBET development (Foucat, 2002). concerned stake holders in tourism includes Ministry of Culture and Tourism, the Bureau of Culture and Tourism, Ecotourism-service providers and attraction site owners, respective local communities, across Ecotourism attractions, non-governmental organizations working, on Ecotourism development, Higher education institutions, media and duties and responsibilities of tourists for community based ecotourism development (CBET Guideline, 2004). However, government agencies are key actors for development of ecotourism activities. Their interest and capacity to involve in the overall tourism development has great value for sustainable development of CBET. Hence, lack of government programs are major barrios to entrepreneurs entering the ecotourism sectors. (Foucat, 2002). Regardless of this briefly stated policy, Ethiopian government hasn't enforced the development activities. There are problems of government guiding, capacity and collaborative relation among stakeholders in the country. This in turn resulted in problem of awareness and engagement of stakeholders to do in collaboration. Local communities need to do independently in disintegrate way rather than doing in cooperation although culture and tourism bureau has developed formal platform to help collaborative work of stakeholders (Experts, 2019). In fact,integration of national policies concerning rural development and ecotourism is often a challenging work for success of CBET in 
developing countries (Foucat, 2002).

Generally, the study provides that regardless of the policy emphasis to benefit local communities from tourism development; lack of engagement, capacity and cooperation of stake holders to involve in tourism activities are among the main challenges of CBET development.

\subsubsection{Lack of Infrastructures and Promotion of the Forest}

Road, renewable electric power, telecommunication network and clean water supply are necessary infrastructures at tourism destinations. It is important to construct and develop roads to link tourism destinations. It affects the accessibility and quality of tourism activity. The development of CBET business can be directly influenced by its accessibility. It is challenging and costly to construct infrastructures and facilities at areas where ridged features of mountains, hills, plateaus, gorges and rivers are widely found despite the fact that they are potential attractions. In this regard, small mountains, hills, plateaus, gorges and rivers are typical features of the kahitaste forest that can be challenges to construct infrastructure and facilities to be accessible although are potential tourism attractions. Ups and downs, erosion, rivers and streams dissect and make the forest difficult to construct infrastructures. Moreover, Ecotourism centers need zoning and construction of road net work to access the each zone each other. It is also essential to construct sufficient facilities like lodges, toilets and water supply. It is expensive and need high budget to apply such activity at such rigged physical features. Thus, physical features of Kahitestsa forest itself can be considered as one of major challenge to develop CBET.

Since the travel and tourism industry is becoming an increasingly competitive market place at international level, where only the best managed and marketed enterprises and destinations are likely to enjoy the competitive market; it requires an effective and appropriate marketing strategy to inform tourists with the right message about destination and encourage them to include in their travel itinerary for experience (Asker, 2010). This fact in Ethiopia, however, is poor. yet tourism infrastructure is at its infancy stage; tourist products are poorly maintained; access to tourist products are difficult and can be inappropriately expensive; and there is a lack of marketing to attract tourists to the country, and a lack of marketing of tourist attractions once tourists are in the country. There is a lack of signage to tourist attractions and it is almost impossible to find brochures or maps of the city or its attractions although the country possesses a plethora of tourist attractions (B. M. K. Robinson AndJ. A. Jonker, 2016).

Kahitestsa forest is affected with this problem. It is not yet promoted as tourism destination in general and CBET in particular except visitation by few attracted local visitors themselves without any service even if there is existence of potential. Culture and tourism bureaus has not researched and promoted as tourism destination due to poor involvement in addition to lack of budget of their bureaus, and there is no any movement from other stake holders. Regardless of this, some of interested tourists visit the area for different purposes without any developed tourism products and services (Expert, 2019). As researcher's observation, there are no developed tourist facilities, accommodations and other services at area. Travelers cannot find there any foods and drinks. They are expected to travel with their own lunch box or without any foods and drinks. In addition to these, travelers can't get tour guides who can provide full information.

\section{Conclusions and Recommendation}

The finding shows that rich natural and cultural tourism resources, accessibility and proper demarcation of the forest, engagement of micro finance (credit and saving) institution towards CBET, engagement of cooperative institutions to involve in CBET activities, availability of tourism policy and ecotourism guidelines in the area are some of opportunities for CBET. In spite of these opportunities, the study also indicates that there are different challenges that can discourage the development of CBET at the study area such as conflict between human and nature, lack of capacity, engagement and cooperation among stakeholders to involve in CBET Business, lack of infrastructures and promotion of the forest are some. Accordingly, the following points are recommended:

> To bring sustainable developed to both local communities and resources, opportunities should be used in sustainable way. Hence, environmentally sound, culturally friendly and economically feasible CBET should be developed. Since the forest has rich potential tourism resources, wildlife tourism, bird watching, controlled hunting, hiking, trekking, agree tourism, geo and sightseeing tourism, cultural tour and photographing form of tourism should be developed (Ayana F.2019). On the other hand, challenges should be minimized. Conservation strategy of the forest should be strengthened to protect illegal use of resources. Thus, Conservation awareness and local communities' ownership of the resources should be implemented; relying on firewood for cooking and lighting should be developed in to use of renewable source of energy such as bio gas, solar energy and other technology options.

$>$ The stakeholders have to work cooperatively for the common goal. Hence, Culture and tourism bureaus as responsible body should develop formal platform to help collaborative work of stakeholders. They should play significant role in supporting CBET development initiatives and Provide training to culture and tourism staffs as well as host communities on basic skills of communication, hospitality, customer service and care, CBET product development, business planning, marketing and promotion of the resources. Local communities should be trained and certified on the tour guiding, food and beverage preparation 
and service, handcraft production, organization of cultural events and other essential services that can diversify economic participation of local communities and bring sustainable development of CBET. Moreover, they should also promote and do marketing activities as new tourism destinations (Ayana F.2019).

$>$ Horse and mule transportation service should be supplied to solve transportation problem and to benefit local communities. Strong engagement and cooperative relationship among key stakeholders of tourism industry should be built to involve in CBET businesses activities. Obtaining financial resources to operate the CBET business for the first few years is among the most important barrier to doing business due to difficulties in obtaining loans from financial institutions, thus there should be a developed especial funding mechanisms/ frameworks for CBET businesses to avoid financial barriers (Ayana f., 2019).

\section{Reference}

Ahmed M. (2017). Review on Impacts of Protected Area on Local Communities' Livelihoods in Ethiopia. Journal of Resources Development and Management, Vol.39, Pp 8-13

Amhara National Regional State (2015). Cooperative association of Amhara National Regional State, proclamation 220/2007 E.C

Amogne A., (2014). Development of community based ecotourism in Borena-Saynt National Park, North central Ethiopia: Opportunities and Challenges. Journal of Hospitality and Management Tourism. 5(1), pp. 1-12.

Asker, S and et. al. (2010). Effective Community Based Tourism: A Best Practice Manual Sustainable Tourism Cooperative Research Centre. Australia. Griffith University.

Ayana F., (2019). An investigation of Tourism Potential, Communities' Awareness and Engagement towards Community Based Ecotourism Development in Kehitastse Forest and Environs, Ethiopia. Journal of Tourism, Hospitality and Sports. Vol.42, Pp11-23.

Blamey, R.K. (2001). Principles of Ecotourism. In D.B. Weaver (Ed.): The Encyclopedia of Ecotourism. Wallingford. CABI, (pp. 4-22).

B. M. K. Robinson AndJ. A. Jonker (2016). Tourism in Ethiopia: An urgent opportunity for economic diversification. African Journal of Hospitality, Tourism and Leisure. 5 (3), Pp 1-21.

BoFED (2012) Development indicators of the Amhara National Regional State of the year 2011/12. Bahir Dar, Ethiopia

Brai G. Boniface and Chris C. (2005), Worldwide destinations: The geography of travel and tourism (4th ed.). Oxford, UK. Elsevier Science Ltd.

Bramwell, B. and Sharman, A. (2000). Approaches to Sustainable Tourism Planning and Community Participation: The case of the Hope Valley. London: Routledge, Pp.17-35

Cater, E. and Lowman, G. (1994). Ecotourism: A Sustainable Option? UK. John Wiley and Sons Inc.

Cresswell, C. and MacLaren, F. (2000). Tourism and National Parks in Emerging Tourism

Countries: Issues and Implications. London. John Wiley and Sons Ltd., pp 283-389

Coad, L., Campbell, A., Miles, L., Humphries, K. (2008). The Costs and Benefits of Protected Areas for Local Livelihoods: a review of the current literature. Working Paper.UNEP World Conservation Monitoring Centre, Cambridge, U.K.

Cole, S. (2006). Cultural tourism, community participation and empowerment: Great Britain Channel View Publications, pp. 89-103

Demeke, D. and Afework, B. (2013). Conservation Challenge: Human-herbivore Conflict in Chebera Churchura National Park, Ethiopia. Pakistan Journal of Biological Sciences, 16: 1758-1764.

Denman, R. (2001). Guidelines for Community Based Ecotourism Development. Washington: Department for International Development (DFID)

Duffy, R. (2002). A trip too far: ecotourism, politics, and exploitation. London. Earth scan.

$\neg \neg \neg \neg \neg$ (2006). Global Environmental Governance and the Politics of Ecotourism in Madagascar.

Journal of Ecotourism, 5 (1 and2), 128-144

Edelman C (2006). "Ecotourism for sustainable development: Highlighting setbacks of communitybased ecotourism."Retrieved from http: www.//esys.ucsd.edu/ on 22/5/13.

Ethiopian Wildlife Conservation Authority (EWCA) (2009). The Value of the Ethiopian Protected Area System: Message to Policy makers.

(2013). Development of a Marketing Strategy for Wildlife Tourism in Ethiopia Addis Ababa: EWCA 9141 p.Gebremarkos W (1998). "The forest resources of Ethiopia: Past and Present.” J. Ethiop. Wild

life Nat. Hist. Soc. Walia.19:10-28.

(2014). National Parks of Ethiopia Brochure

(2015). Ecotourism potentials of Ethiopia Booklet Ethiopian Tourism Commission (ETC). (1995). Regional tourism development plan for North, East and West Ethiopia (Unpublished material)

Fennell, D.A. (1999). Ecotourism development: international community, and site Perspectives (2nd ed). London. 
Foday Y. (2015). Model for sustainable tourism development for Least Developed Countries (LDCs). African Journal of Hospitality, Tourism and Leisure Vol. 4 (2)

Foucat, V. A. (2002). Community Based Ecotourism Management Moving Towards Sustainability in Ventanilla, Oaxaca, Mexico, Ocean and Coastal Management. 45: 511- 529

Green, R. and K. Higginbottom (2001). The Negative Effects of Wildlife Tourism on Wildlife: With a Focus on Non- Consumptive Free-Ranging Terrestrial Wildlife Tourism. Brisbane. CRC for Sustainable Tourism

Habtamu, D. (2016). Assessment of Human-Wildlife Conflict in Gimbo Woreda, Kafa Zone Southern Nations Nationalities and Peoples Region (SNNPR), Ethiopia: MSc Thesis, Addis Ababa University

Hardyment CL (2003). Ecotourism definition; Pidra, Blanca ecotourism consultant. Retrieved from www.piedrablanca.org/ecooturismdefinition.html on 22/10/12.

Hayward P (2000). Leisure and tourism. Heinemann Educational Publishers; the Bath Press Ltd, Great Britain.

Henze, B.P. (2007). Ecotourism in Ethiopia: Opportunities and ideas. Conference of IDR/AAU. Retrieved from www.irrrob.org/ecotourism-in- ethiopia.html.on28/6/09

Hill, C. (2000). Conflict of Interest between People and Baboons. Crop Raiding in Uganda. International Journal of Primatology, 21: 299-315.

Hongshu, W. and Min, T. (2009). Research on Community Participation and Environmental Management of Ecotourism: North East Forestry University of China. International Journal of Business and Management

Kassegn B. and Endalkachew T. (2018). Opportunities and Challenges for Wildlife Conservation: The Case of Alatish National Park, Northwest Ethio. African Journal of Hospitality, Tourism and Leisure, 7 (1) Pp 113

Kelly, E. (2009). An Assessment of the Potential for Developing Ecotourism in the San Francisco, Menendez Sector of El Imposible National Park. El Salvador. Alaska University press

Kiss, A. (2004). Is community-based ecotourism a good use of biodiversity conservation? Funds? Trends in Ecology and Evolution, 19(5), 232-236. Retrieved from www.sciencedirect.com on 22/05/99

Lowmen, M. (2004). Ecotourism and its impact on forest conservation: Action Bioscies. American institute of Biological Sciences www.actionbioscience.org/environment/lowman.html on 14/9/09

McKercher, B. and Robbins, B. (1998). Business Development Issues Affecting Nature-Based Tourism Operators in Australia. Journal of Sustainable Tourism, 6 (3), 172-88

Miles, P. (2014). Uganda Inclusive Tourism Program - A Model for Public Private Partnerships (Programme presented to the Uganda Tourism Board, Uganda).

Ministry of Culture and Tourism of Ethiopian (2009). Ethiopian Tourism Development Policy, unpublished document

(2011). Community Based Ecotouris Guideline, unpublished document

Pearce. F. 2005. Humans losing out to Africa's big game industry.New Scientist 2495:21

SDPASE, (2008). Protected Areas of Ethiopia: Information Bulletin

Silva, Gabriela and McDill, Marc E. (2004). Barriers to Ecotourism Supplier Success: A Comparison of Agency and Business Perspectives. Journal of Sustainable Tourism, 12 (4), 289-305

Sproule, K. W. (1996). Community-based ecotourism development: Identifying Partners in the process, The Ecotourism Equation and Measuring the Impacts, 233-50

Sofield, H. B. T. (2003). Empowerment for sustainable tourism development. Oxford UK, Elsevier Science Ltd.

Stephen, W. (2009). Tourism geography: new synthesis ( $2^{\text {nd }}$ ed.) USA and Canada. Rout ledge

Teyiba A. Mustefa S. Mulugeta F. (2017). Ecotourism Development in Protected Area: The Case of Senkele Swayne's Hartebeest Sanctuary (SSHS), West Arsi Zone, Oromia Region, Ethiopia. Journal of Tourism, Hospitality and Sports., Vol.26, Pp 43-56

Tshepiso J. and Takalani R. (2019). Benefits of sustainable rural tourism: a case of Nqileni village, Eastern Cape Province, South Africa. African Journal of Hospitality, Tourism and Leisure, Volume 8 (3), Pp 1-11

UNWTO, (1997). Word Tourism Leaderse Meeting on the Social Impacts of Tourism: Paper Prepared for, World Tourism Leaders. Retrieved from http:/www.unwto.org/ 2016

Viva Ethiopia Tour (2014). Natural Tourism Attractions of Ethiopia: retrieved from http:/www.vivaethio.tour.org/2016

Weaver, D. and Lawton, L. (2007). Twenty years on: The State of Contemporary Ecotourism Research. Tourism Management, 28, 1168-1179

Weaver, D., Glenn, C. and Rounds, R. (1996). Private Ecotourism Operations in Manitoba, Canada. Journal of Sustainable Tourism, 4 (3), 135-46

WWF International, (2001) guidelines for community based eco-tourism development

WTO-UNEP (2002). World Ecotourism Summit Final Report. Madrid, Spain 